\title{
Dextran-Coated Charcoal Immunoassay of Insulin
}

\author{
P.M. Keane*, J. Pearson and W.H.C. Watuker \\ Dept of Chemical Pathology, Bristol Royal Infirmary
}

Received: November 30, 1967

\begin{abstract}
Summary. 1. The use of dextran-coated charcoal allows a rapid, simple and relatively precise radioimmunoassay of insulin. - 2. The factors affecting the selectivity of coated charcoal for insulin and antibody-bound insulin have been examined and optimum operating conditions selected. - 3. The original method has been modified to allow the use of a commercially available antiserum. 4. The accuracy and precision of the method have been compared with those of a double antibody technique.
\end{abstract}

Dosage immunologique de l'insuline avec le charbon recouvert de dextran

Résumé. 1. L'utilisation de charbon recouvert de dextran permet un dosage radioimmunologique de l'insuline rapide, simple et relativement précis. -2 . Les facteurs affectant la sélectivité du dextran-charbon pour l'insuline et les complexes insuline-anticorps ont été examinés et les meilleures conditions d'opération ont été sélectionnées. - 3. La méthode originale a été modifiée afin de permettre l'usage d'un antisérum commercial. - 4. La justesse et la précision de la méthode ont été examinées et comparées avec celles de la méthode au double anticorps.

Immunologische Insulinbestimmung mit dextranvorbehandelter Tierkohle

Zusammenfassung. 1. Die Verwendung von dextranvorbehandelter Tierkohle erlaubt eine schnelle, einfache und relativ präzise radio-immunologische Insulinbestimmung. - 2. Die Faktoren, die das unterschiedliche Ansprechen von dextranvorbehandelter Tierkohle auf freies und antikörper-gebundenes Insulin beeinflussen, wurden untersucht und die günstigsten Bedingungen für die Durchführung der Untersuchung herausgearbeitet. 3. Diese Modifikation der Originalmethode erlaubt auch die Verwendung des handelsüblichen Anti-Insulin-Serums. - 4. Die Richtigkeit und die Genauigkeit der beschriebenen Methode wurden mit der eines Doppel-AntikörperVerfahrens verglichen.

Key-words: Plasma Insulin, radioimmunoassay, insulin, dextran, albumin, gamma globulin-charcoal complexes, comparison with double antibody method.
In the immunoassay of peptide hormones unlabelled hormone is measured by the extent of its competition with radioactively labelled hormone for specific antibody binding sites. A variety of techniques has been employed for the separation of antibody-bound and free peptide: chromatoelectrophoresis [13]; gel filtration [2]; ion exchange resin $[7,8,9]$ and precipitation of the antibody-bound fraction with sodium sulphite [3] or with a second antibody $[4,10]$. For the assay of insulin, HeRBERT et al [5], have described the use of dextran-coated charcoal, which adsorbs free insulin but not that bound to antibody. This system has attractions of speed and simplicity, and we have explored the interactions involved in it and introduced modifications which allow a commercially available anti-insulin antiserum to be used satisfactorily.

\section{Methods}

All studies of adsorption to charcoal were made using radio-iodinated materials. The proportion of total radioactivity adsorbed to charcoal $(B c)$ was obtained by counting the activity in the supernatant after centrifugation and decantation, and comparing this with the total radioactivity in the system. Measurements of radioactivity were made in a well-type scintillation counter using a final counting volume of $4 \mathrm{ml}$. All reaction volumes were $4 \mathrm{ml}$ containing 125 $\mathrm{mg} / 100 \mathrm{ml}$ dextran and $50 \mathrm{mg}$ charcoal (see appendix).

* Present address: Department of Pathology, U.W.I., Jamaica.

\section{Albumin-Dextran-Charcoal Interaction}

When ${ }^{131} \mathrm{I}$-albumin was treated with dextran coated charcoal, adsorption was complete within $1 \mathrm{~min}$ and no further uptake was demonstrable in the next $10 \mathrm{~h}$. Subsequent addition of unlabelled albumin to give a final concentration of $100 \mathrm{mg} / 100 \mathrm{ml}$ failed to displace any of the labelled albumin adsorbed to charcoal after $10 \mathrm{~h}$ further incubation. For practical purposes, albumin adsorption can be considered instantaneous and irreversible. It will, however, be shown later that prolonged contact of dextran-coated charcoal with albumin reduced the capacity of the charcoal to bind insulin. This effect was progressive, at least up to 30 min, and may perhaps be due to secondary interactions between albumin and dextran-charcoal complexes.

In the absence of dextran, both the proportion and the absolute amount of albumin adsorbed by charcoal varied greatly with the albumin concentration. In contrast, dextran-coated charcoal adsorbed a constant proportion of albumin from solutions initially containing $90-700 \mathrm{mg} / 100 \mathrm{ml}$ (see Fig. 1).

\section{Guinea Pig $\gamma$-Globulin-Albumin-Dextran- Charcoal Interaction}

Under all the conditions examined, some ${ }^{131} \mathrm{I}$ guinea pig $\gamma$-globulin was adsorbed by charcoal. The amount adsorbed varied with the concentration of dextran present and with the amount and type of 
albumin present (Table 1). A $\gamma$-globulin uptake was obtained when human albumin (Sigma, grade III) or egg albumin (B.D.H.) was present together with dextran. Increasing the concentration of dextran from $125 \mathrm{mg} / 100 \mathrm{ml}$ to $500 \mathrm{mg} / 100 \mathrm{ml}$ did not alter the $\gamma$-globulin adsorption. The effect of albumin concentration is shown in Fig. 2: the uptake of $\gamma$-globulin was unchanged over the range $100-700 \mathrm{mg}$ albumin $/ 100$ $\mathrm{ml}$. All uptake measurements quoted were made after contact with charcoal at room temperature for $1 \mathrm{~min}$. A further slow uptake occured at room temperature for up to $30 \mathrm{~min}$, but when the temperature of the reactants was maintained at $5^{\circ} \mathrm{C}$, the combination human (or egg) albumin dextran-charcoal adsorbed $12 \%$ of $\gamma$-globulin at 1 min and no further uptake was demonstrable in the next $30 \mathrm{~min}$.

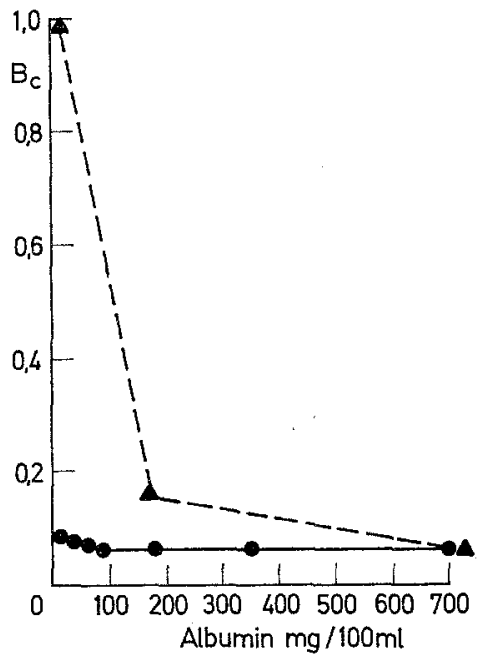

Fig. 1. Adsorption of albumin by charcoal with no dextran present, $A-A$ and with dextran $125 \mathrm{mg} / 100 \mathrm{ml}$

Bc. fraction bound to charcoal

Table 1. Proportion of guinea pig ${ }^{131} \mathrm{I}_{-\gamma-g l o b u l i n}(2 \mathrm{mg} / 100$ $m i)$ adsorbed onto charcoal (BC) in the presence of different concentrations of dextran and types of albumin

\begin{tabular}{llll}
\hline Albumin & & $\begin{array}{l}\text { Dextran } \\
\mathrm{mg} / 100 \mathrm{ml}\end{array}$ & $\mathrm{Bc}$ \\
\hline type & $\mathrm{mg} / \mathbf{1 0 0 \mathrm { ml }}$ & $\mathbf{1 2 5}$ & $\mathbf{0 . 4 0}$ \\
\hline- & - & $\mathbf{5 0 0}$ & 0.23 \\
human & 175 & - & 0.25 \\
human & 175 & $\mathbf{1 2 5}$ & 0.12 \\
human & 175 & $\mathbf{5 0 0}$ & 0.12 \\
egg & 175 & 125 & 0.12 \\
bovine & 175 & 125 & 0.28 \\
\hline
\end{tabular}

HERBERT et al [5]. note that different albumins have different effects on the selectivity of coated chareoal for unbound insulin and antibody. The albumin preparation they recommend is unavailable in this country, but we infer from Fig. 2 of their paper that a $20 \%$ adsorptive loss of $\gamma$-globulin also occurred in their assay procedure.

This adsorption of guinea pig $\gamma$-globulin onto charcoal would represent loss of antibody-bound- insulin from the supernatant in the assay, and the validity of the assay procedure in the presence of plasma will depend on this loss being unaffected by the plasma proteins added. Addition of $0.1 \mathrm{ml}$ volumes of undiluted horse serum, guinea pig serum or 6 different human plasmas resulted in no detectable change in the proportion of ${ }^{131} \mathrm{I}-\gamma$-globulin absorbed. There is

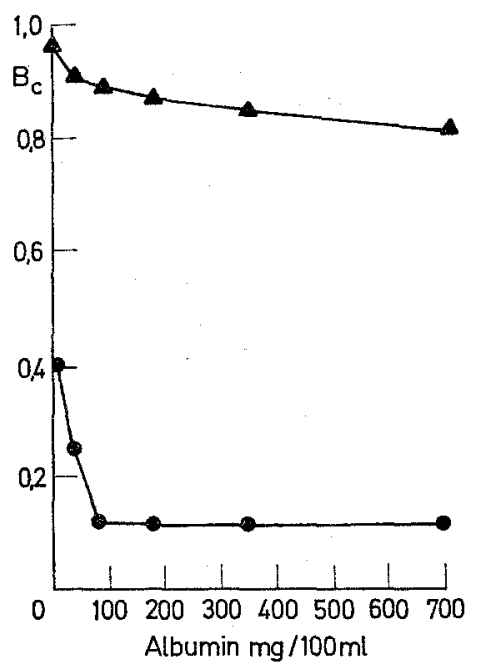

Fig. 2. Adsorption of guinea pig $\gamma$-globulin insulin $\boldsymbol{A}-\boldsymbol{A}$ by charcoal in the presence of dextran $125 \mathrm{mg} / 100 \mathrm{ml}$ with varying albumin concentrations. Bc. fraction bound to charcoal

therefore no evidence of a general interference with guinea pig $\gamma$-globulin uptake when plasma is present, although we cannot exclude the possibility that individual plasmas might have such an effect. If this were considered a serious hazard, ${ }^{131} \mathrm{I}-\gamma$-globulin controls would have to be set up for each plasma. Such a procedure was found necessary by WELBORN and FrASER [12] in their double antibody technique for insulin.

\section{Insulin-Albumin-Dextran-Charcoal Interaction}

In the absence of dextran and albumin, charcoal will adsorb almost $100 \%$ of free insulin, but there will also be marked adsorption of $\gamma$-globulin and hence of bound insulin. Uptake of guinea pig $\gamma$-globulin is minimised by the presence of albumin and dextran together, but these materials prevent complete uptake of free insulin. The relationship between the uptake of $\gamma$-globulin and insulin at varying albumin concentrations is shown in Fig. 2. The greatest adsorption of insulin with least loss of $\gamma$-globulin from the supernatant occurrs at an albumin concentration of $100 \mathrm{mg} /$ $100 \mathrm{ml}$. A working concentration of $175 \mathrm{mg} / 100 \mathrm{ml}$ was chosen as this was well removed from the region of increasing $\gamma$-globulin adsorption, and there is little change in insulin uptake. Under the conditions selected, about $11 \%$ of free insulin remains unadsorbed to coated charcoal. This 'blank' value varies with different 
batches of iodinated insulin over the range $8-30 \%$; it tends to increase with storage of the labelled hormone, and has been found to be independent of the concentration of labelled or unlabelled insulin over the range $0.015-60.0 \mu \mathrm{U} / \mathrm{ml}$ in the final reaction mixture. Examination of this blank by the chromatoelectrophoretic technique of YaLow and Berson [13] has shown it to consist entirely of material reacting as 'undamaged' insulin.

When $0.1 \mathrm{ml}$ plasma is present in the reaction mixture the 'blank' value is always increased by about $3 \%$. This 'blank' increment due to plasma cannot be abolished by increasing the concentration of albumin or dextran, and as the increment varies with different plasmas it is necessary to correct for this by using separate plasma 'blanks' from which antibody is omitted (see Fig. 5 and 6 ).

If albumin and coated charcoal solutions are mixed and left $30 \mathrm{~min}$ before adding insulin solution, the 'blank' value increases to $25 \%$ although the uptake of $\gamma$-globulin is not diminished. It is therefore essential that these two solutions are not premixed before addition to the incubation mixture.

\section{Insulin-Antibody Interaction}

The time relationship of interaction between insulin and antibody at the concentration used in the assay is shown in Fig. 3. When $25 \mu \mathrm{U} / \mathrm{ml}$ insulin was present,

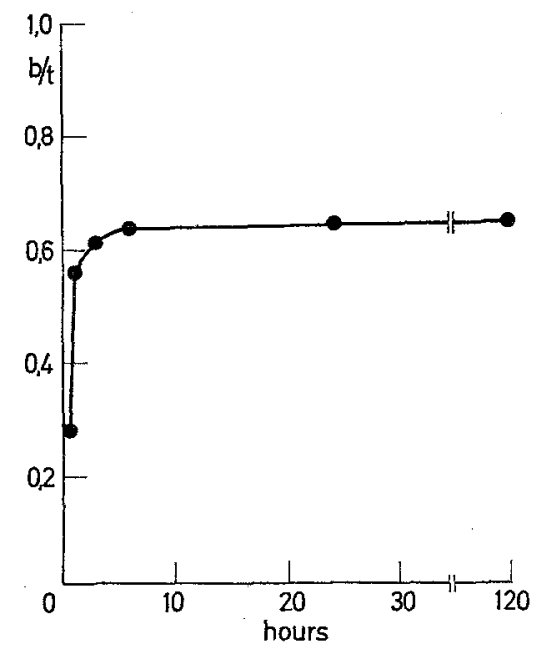

Fig. 3. Proportion of labelled insulin bound to antibody $(b / t)$ with increasing incubation time

the proportion bound to antibody $(b / t)$ increased rapidly during the first $3 \mathrm{~h}$ incubation at $5^{\circ} \mathrm{C}$. Maximum interaction had occurred at $24 \mathrm{~h}$ and remained unchanged at $120 \mathrm{~h}$. The presence of $160 \mu \mathrm{U} / \mathrm{ml}$ unlabelled insulin in the system did not alter these time relationships. When an excess of unlabelled hormone $(500 \mu \mathrm{U} /$ $\mathrm{ml}$ ) was added after the labelled hormone had reached equilibrium with the antibody, no displacement of labelled insulin from the antibody could be demonstra- ted even after further incubation for $24 \mathrm{~h}$. The combination of insulin with the particular antibody studied is therefore effectively irreversible although this is not an invariable characteristic of such antibodies ${ }^{14}$.

\section{Assay Procedure}

In the procedure of HERBERT et al. $\left[^{5}\right]$, insulin and antibody were incubated at $37^{\circ} \mathrm{C}$ for $2 \mathrm{~h}$ in a reaction volume of $4 \mathrm{ml}$. With the present antibody, use of such conditions resulted in calibration curves of very poor sensitivity, and adequate binding of insulin could be obtained only with high concentrations of antibody. Reduction of the incubation temperature to $5^{\circ} \mathrm{C}$ allowed the use of lower concentrations of antibody with improved sensitivity but incubation periods of $96 \mathrm{~h}$ were required. This prolonged incubation appeared to result in damage to the hormone. When the reaction volume was reduced, without altering the quantity of antibody present, there was a progressive increase in binding with a decrease in the time required to reach equilibrium (Fig. 4). The present antibody could be used to produce satisfactory standard curves when incubation was carried out at $5^{\circ} \mathrm{C}$ for $18 \mathrm{~h}$ in a reaction volume of $0.3 \mathrm{ml}$.

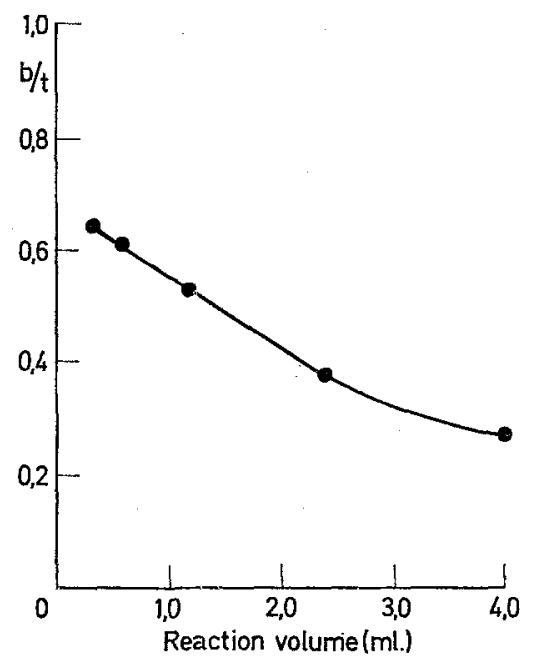

Fig. 4. Effect of reaction volume on proportion of labelled insulin bound $(b / t)$ to a fixed amount of antibody

A flow sheet of the assay is shown in Fig. 5. A calibration curve is prepared by plotting $(T s-C s)$ against the amount of unlabelled insulin added. The insulin present in a plasma sample is read from this curve using the corrected plasma supernatant acti$\operatorname{vity}(T p-C p)$.

\section{Precision of the Method}

Estimations on a single plasma included in 19 consecutive assays, gave a mean insulin content of $32.0 \mu \mathrm{U} / \mathrm{ml}$ with a coefficient of variation for a single estimate of $14.4 \%$. The within batch coefficient of 
variation was $14.3 \%(\hat{x}=30.0 ; n=10)$. By comparison, the precision between batches of the same plasma assayed by a double antibody technique (see appendix) based on the mean of triplicate estimations was $18.6 \%$ $(\hat{x}=55.5 ; n=11)$.

\begin{tabular}{|c|c|c|c|c|}
\hline & $\begin{array}{l}\text { Stand. } \\
\text { ard } \\
\text { ml. }\end{array}$ & $\begin{array}{c}\text { Plasma } \\
\mathrm{ml}\end{array}$ & $\begin{array}{l}\text { Anti- } \\
\text { body } \\
\text { ml }\end{array}$ & $\begin{array}{c}\text { Albu- } \\
\text { min- } \\
\text { Buffer } \\
\text { ml }\end{array}$ \\
\hline $\begin{array}{l}\text { Standard, test (Ts) } \\
\text { Standard, blank (Cs) }\end{array}$ & $\begin{array}{l}0.1 \\
0.1\end{array}$ & - & 0.1 & $\overline{0.1}$ \\
\hline $\begin{array}{l}\text { Plasma, test (Tp) } \\
\text { Plasma, blank (Cp) }\end{array}$ & $\overline{-}$ & $\begin{array}{l}0.1 \\
0.1\end{array}$ & $\begin{array}{l}0.1 \\
-\end{array}$ & $\overline{0.1}$ \\
\hline
\end{tabular}

Incubate $18 \mathrm{~h}, 5^{\circ} \mathrm{C}$.

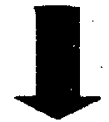

Add $2 \mathrm{ml}$ albumin buffer at $5^{\circ} \mathrm{C}$

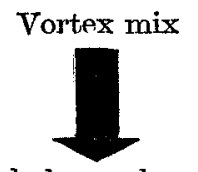

Add $2 \mathrm{ml}$ coated charcoal suspension at $5^{\circ} \mathrm{C}$

Keeping the suspension well mixed with a magnetic stirrer Vortex mix

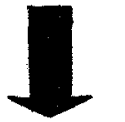

Centrifuge $10 \mathrm{~min}(2000 \mathrm{rpm})$

Decant supernatant and count ${ }^{125} \mathrm{~T}$-insulin in well type Scintillation Counter. (ECKO)

All incubations were carried out in plastic tubes.

Fig. 5. Flow sheet of assay procedure

\section{Validation of Method}

I. Assay of insulin in increasing volumes of plasma. When a plasma sample was added to an assay system in volumes ranging from 0.05 to $0.3 \mathrm{ml}$ with appropriate addition of buffer to maintain uniform reaction volume in tests and standards, the assayed insulin/ml plasma was relatively constant despite large changes in the plasma blank $(C p)$. If the fixed standard blank $(C s)$ was applied to the plasma results, the apparent assayed concentration was highly dependent on the concentration of plasma in the incubation mixture (Fig. 6),

II. Assay of insulin in increasing dilutions of plasma. Fig. 7 shows the results of assays carried out on increasing dilutions of the same plasma, originally containing $180 \mu \mathrm{U} / \mathrm{ml}$ insulin. There is excellent correlation between insulin found and expected except in the undiluted and the most dilute sample. The calibration curve lacks sensitivity in the region beyond $100 \mu \mathrm{U} / \mathrm{ml}$, and its precision is excessively affected by variations in blank values. Because of this, samples falling in this region are always reassayed after dilution. The estimate on the most dilute sample is inaccurate because of the impairment of precision that occurs when the amount of unlabelled insulin present becomes commensurate with the amount of labelled insulin

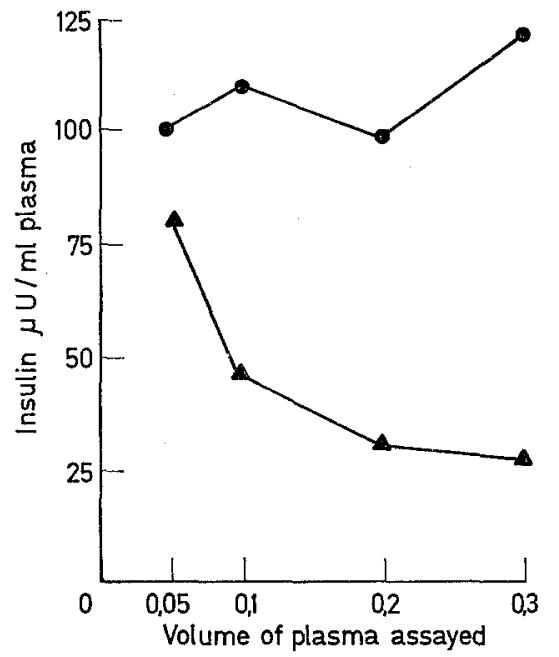

Fig. 6. Effect of increasing volumes of plasma in the assay system. -1 with subtraction of $C p ; \mathbf{A}-\mathbf{\Delta}$ with subtraction of $C s$

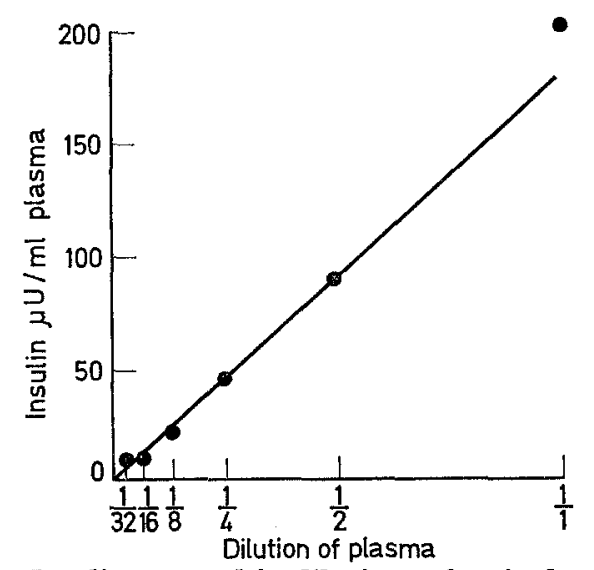

Fig. 7. Insulin assayed in dilutions of a single plasma

added [11]. Such low values may be assayed more precisely by a 'late addition' technique [4], in which labelled hormone is added to the incubation mixture $24 \mathrm{~h}$ after addition of the unlabelled hormone. Fig. 8 shows the standard curves obtained with simultaneous and with late addition of the labelled hormone.

III. Recovery of insulin added to plasma. Human plasma samples were assayed before and after addition of $20-200 \mu \mathrm{U}$ beef insulin $/ \mathrm{ml}$, by the present method and by the double antibody technique. The results are 
shown in Fig. 9. The mean recovery using the coated charcoal assay was $103 \% \pm 24 \%$ (1 S.D.); and for the double antibody technique, $117 \% \pm 22 \%$ (1 S.D.). The $17 \%$ overestimation by the latter technique is significant $(t=3.5 ; p<0.01)$.

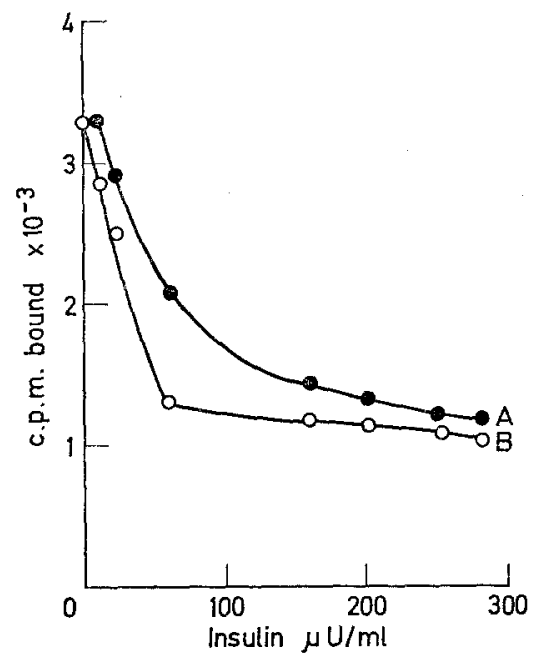

Fig. 8. Increased sensitivity with late addition (B) compared with simultaneous addition (A)

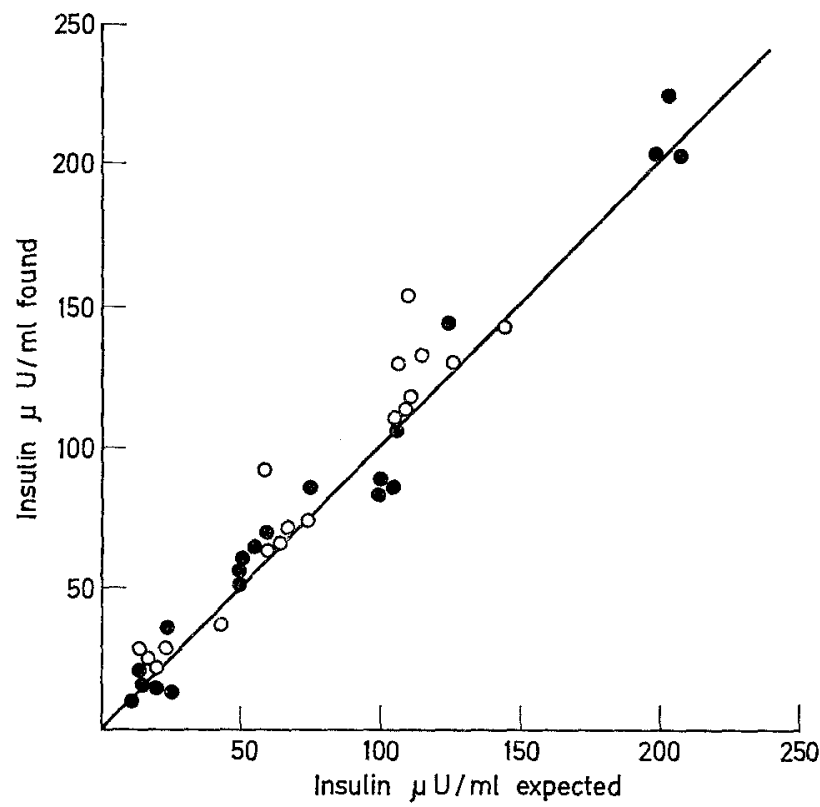

Fig. 9. The recovery of beef insulin added to human plasma samples : dextran coated charcoal assay; 0 : double antibody assay

IV. Comparison of two assay procedures. 25 plasmas were assayed by the present method and by the double antibody procedure. The results are shown in Fig. 10. There is a tendency for results to be higher by the double antibody technique than by the coated charcoal assay. The results of the recovery experiments indicate that this discrepancy is due to overestimation by the double antibody technique. Other workers have obtained satisfactory recoveries with the double antibody assay [1] and we cannot explain the overestimation in our hands.

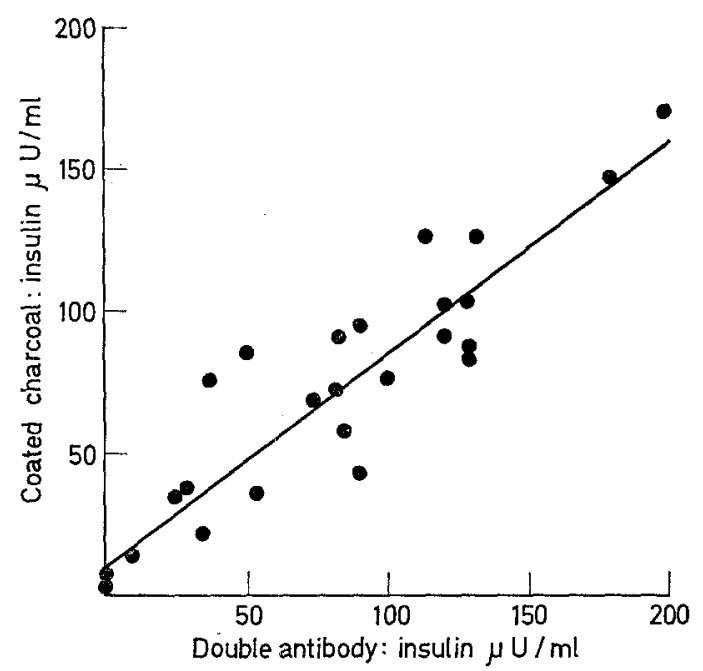

Fig. 10 Comparison of assays of plasmas by coated charcoal and double antibody methods $\mathrm{y}=10 \cdot 5+0 \cdot 745 \mathrm{x}$.

\section{Appendix}

Buffer, dextran, charcoal and dextran-coatedcharcoal were obtained from the sources described by HERBERT et al. [5] and were made up to their formulations. In the preparation of the albumin-buffer solution, Human Serum Albumin (Sigma, Grade III) was substituted for Albumisol.

${ }^{125}$ I-ox insulin (Radiochemical Centre, Amersham, Code I M 38) was stored at $5^{\circ} \mathrm{C} .0 .1 \mathrm{ml}$ diluted to $5 \mathrm{ml}$ with albumin-buffer was sufficient for 50 assay tubes.

Anti-porcine insulin guinea pig antibody (Burroughs Wellcome, London) was reconstituted in albuminbuffer to give a final dilution of $1 / 16000$.

Purified ox insulin (Burroughs Wellcome) with a biological activity of $23.1 \mathrm{I}$. U./mg was made up in $0.003 \mathrm{M} \mathrm{HCl}$ at a concentration of $200 \mu \mathrm{g} / \mathrm{mI}$ and stored at $-20^{\circ} \mathrm{C}$. It was diluted in albumin-buffer to give the required working standards.

${ }^{131}$ I-human serum albumin (Radiochemical Centre, Amersham, Code I.B. 17 P.) was diluted with buffer or albumin-buffer to give the required working concentrations of albumin.

131I-guinea pig $\gamma$-globulin was isolated by the technique of Welborn and Fraser [12] and iodinated by the method of HoNTER and GreEnwood [6]. It was diluted 1/100 with working strength anti-insulin antibody. The free ${ }^{131}$ I-iodide content of both albumin and $\gamma$-globulin preparations was shown to be less than $0.7 \%$ by ultrafiltration.

Egg albumin was obtained from British Drug Houses; bovine serum albumin from Armour Pharmaceutical Co. Itd.

Double antibody reagents and method: Radiochemical Centre, Amersham, Data Sheet 5616. 


\section{References}

1. BuChanar, K.D., and M.T. McKiddie: Experience with the immunoprecipitation technique of insulin assay with reference to sensitivity, precision and specificity. Clin. chim. Acta, 15, 315-320 (1967).

2. GENUTh, S., L.A. Frohman, and H.E. Lebovitz: A radioimmunological assay method for insulin using insulin-125I and gel filtration. J. clin. Endocr. 25, $1043-1049$ (1965).

3. Grodsky, G.M., and P.H. ForshaM: An immunochemical assay of total extractable insulin in man. J. clin. Invest. 39, 1070-1079 (1960).

4. Hates, C.N., and P.J. R.ANDLE: Immunoassay of insulin with insulin-antibody precipitate. Biochem. T. 88, $137-146(1963)$.

5. Herbert, V., K-S. LaU, C.W. Gotthmeb, and S.J. BLETCHER: Coated charcoal immunoassay of insulin. J. clin. Endocr. 25, 1375-1384 (1965).

6. Hunter, W.M., and F.C. GRewnwood: Preparation of iodine-131 labelled growth hormone of high specific activity. Nature 194, $495-496$ (1962).

7. LazarUs, L., and J.D. Young : Radioimmunoassay of human growth hormone using ion exchange resin. J. clin. Endocr. 26, 213-218 (1966).
8. Meade, R.C., and H.M. KuITGaARD. A simplified method for (the) immunoassay of human serum insulin. J. Nucl. Med. 3, 407 (1962).

9. Merant, F., H. Ditschuneit, K.M. Bartelt: Über die radioimmunologische Bestimmung Von. Insulin im. Blut. Klin. Wschr. 43, 1000-1007 (1965).

10. Morgan, C.R., and A. Lazarow: Immunoassay of insulin using a two-antibody system. Proc. Soc. exp. Biol. 110, 29-32 (1962).

11. Walker, W.H.C., P.M. Keane, and J. Pearson: Some theoretical aspects of immunoassay. In preparation.

12. Whlborn, T.A., and T.R. Fraser: The double antibody immunoassay of insulin. Diabetologia 1, 211$217(1965)$.

13. YALOW, R.S., and S.A. Berson: Immunoassay of endogenous plasma insulin in man. J. clin. Invest. 39, $1157-1175(1960)$

14. Yatow, R.S., S.A. Berson, S.M. GlroK, and J. RoTH: Immunoassay of protein and peptide hormones. Metabolism 13, 1135-1153 (1964).

Dr. P.M. KFANT

Royal Hospital

Department of Pathology

Bristol 2, England 